\section{Doom-laden Sundance}

The Sundance Film Festival in Park City, Utah, sets the agenda for independent cinema. At this year's festival, which runs until 31 January, science-related films are most concerned with disaster scenarios, both real and imagined.

A handful of documentaries chart the spread of man-made catastrophes. Countdown to Zero exposes the postcold war proliferation of nuclear weapons and public denial of their danger. Climate Refugees tracks the coming wave of human migration caused by rising waters and changing weather, from Bangladesh to Sudan. On a lighter note, Australian film-maker Mark Lewis returns with a sequel to his classic 1988 documentary about the environmental havoc caused by the invasive Australian cane toad - this time in three-dimensional splendour.

A contrasting selection of documentaries offers some hope of escape from these planetary woes. Life 2.0 follows the masses who retreat into the virtual sanctuary of Second Life. Space Tourists tracks a wealthy Iranian engineer's quest to become the "first female private space explorer" with help from the Soviet space programme in Kazakhstan.

The slate of fictional films also reveals a preoccupation with end-of-time scenarios. Pumzi, a Kenyan sciencefiction short, depicts a botanist trying to nurture a single plant in parched post-apocalyptic Africa. The monster movie Splice taps into fears of genetic engineering by raising the possibility of a vicious human-animal chimaera. And with a gentler touch, Obselidia follows a salesman whose efforts to compile an encyclopaedia of obsolescent things leads him to a scientist who predicts the end of civilization.

"Not all the films are doom and gloom," said John Nein, who organized a panel on the 'discovery process' that will bring together film-makers and scientists, sponsored by the Alfred P. Sloan Foundation. "Others provide a beautiful reflection of our relationship to nature."

Jascha Hoffman is a writer based in San Francisco, California.

\title{
Turin's criminology museum
}

\author{
Museum of Criminal Anthropology \\ 'Cesare Lombroso' \\ Turin, Italy
}

These days Cesare Lombroso is often considered a figure of fun, a flamboyant crazy who insisted that a criminal - or, indeed, a genius - could be recognized by the cut of his jaw or the slope of his forehead.

The self-styled anthropological criminologist might not cut muster as a rigorous scientist today, but his ideas were influential. In their time, they contributed to debate on the nature of free will and personal responsibility for crime. Lombroso held that a born criminal was beyond redemption and that the death sentence was necessary to protect society. But he also believed in rehabilitation for those he called criminaloids - criminals who displayed fewer of the morphological characteristics of delinquency such as a small head, large ears, a skull displaying prominent brow arches over large eye orbits, or bulky jaw bones. He fought for humane asylums for them.

The revamped Museum of Criminal Anthropology 'Cesare Lombroso', which opened in new premises in Turin in November - a century after Lombroso's death - places his sometimes revolutionary, often messy, but certainly voluminous, work in context.

Lombroso was born in Verona, in the north of Italy, in 1835 and lived through an era in which radical new scientific discoveries and theories - such as Charles Darwin's theory of evolution and Sigmund Freud's theory of mind - were having a forceful impact on society. Science was also influencing police work, with the introduction of fingerprinting and photography into forensics in the last half of the nineteenth century.

Lombroso subscribed to the positivist view that scientific knowledge must be based only on fact and observation, and he enthusiastically measured things, particularly humans. The measure of a man - in particular, detailed measurements of his head and features - could be the measure of personality, Lombroso decided. He collected artefacts to support his work, in particular the paraphernalia of criminals. On display in the museum are murder weapons, innumerable skulls, the artworks of prisoners and asylum inmates and photographs of their tattoos. In Lombroso's eyes, the tattoos provided evidence of the atavism that made the individual delinquent.

His theory of atavism held that many criminals - as well as geniuses and the insane - were regressive throwbacks to a more primitive evolutionary state. Adopting the view of his German contemporary Ernst Haeckel that 'ontology recapitulates phylogeny', Lombroso saw infancy as a period of development corresponding to that of primitive man: get stuck in it and you get stuck in a primitive state that fosters deviant behaviour.

Lombroso's era was also a politically turbulent one in Italy. Years of wars of independence came before the country's final unification in 1870. Levels of crime, from pickpock eting to murder, were perceived as unprece dentedly high in these unstable times.

The concept that criminal behaviour could have biological roots was reassuring to the public. Science could not only help to detect criminals, but it could also help to clean society of them. Lombroso asked the appropriate questions, but his scientific approach to answering them was muddled. He relied on his intuition, and he tended to select the data to fit his theories.

The first rooms of the small museum set out the social, scientific and political contexts within which Lombroso lived and worked. Included are Italy's first epidemiological charts, which Lombroso prepared, showing the distribution of disease and attributes such as height throughout the newly unified country. Visitors can also see a documentary movie shot locally in 1908 , which was the first in the world to film the insane for clinical purposes.

Other rooms display his personal collections. Lombroso bequeathed his own skeleton to complete his bizarre assembly of objects. It hangs in pride of place amid the displays.

Alison Abbott is Nature's senior European correspondent.

See go.nature.com/BAuJzt for more details. 